\title{
Psychometric properties of the Portuguese version of the Relational Interdependent Self -Construal scale
}

\author{
Gabriela Gonçalves ${ }^{1,2}$, Cátia Sousa ${ }^{1,2}$, Joana Santos ${ }^{1,2}$, Alexandra Gomes ${ }^{1,2}$, Andreia Santa- \\ Rita $^{1}$, Sofia Hipólito ${ }^{1}$, Catarina Rodrigues ${ }^{1}$ \& Marta Reis ${ }^{1}$ \\ ${ }^{1}$ Universidade do Algarve, Portugal \\ ${ }^{2}$ CIEO - Research Centre for Spatial and Organizational Dynamics, Universidade do Algarve, Portugal
}

\begin{abstract}
Relational interdependent self-construal (RISC) can be described as the degree to which the individuals define themselves in terms of their intimate relationships. Due to the significance that this construct and its associated measurement, the RISC scale, have in individual and social processes, we conducted two studies in order to validate the scale for the Portuguese population. The 11 item onedimensional RISC scale was translated into Portuguese and its psychometric properties were analysed with two samples: 399 participants for Study 1 (62.9\% women and 30.8\% men, aged between 18 and 59 years $-M=26.4 ; S D=8.90)$ and 292 participants for Study $2(57.9 \%$ women and $42.1 \%$ men, aged between 17 and 59 years $-M=26.37 ; S D=8.87$ ). The results confirmed the one-dimension scale structure, showing good values of validity and model adjustment $(\mathrm{CFI}=0.92$; $\mathrm{TLI}=0.87$; NFI $=0.89$; RMSEA $=0.09$ ). The RISC-P scale proved to be invariant between gender, and significant differences between genders were found, notably that women have higher values of RISC. The good psychometric indicators and model adjustment validates the use of this version for the Portuguese population in many research settings (e.g. control for social desirability effect, analysis of convergent and predictive validity).
\end{abstract}

Keywords: RISC (Relational Interdependent Self-Construal); Scale; Adaptation; Gender invariance measure.

Propriedades psicométricas da versão Portuguesa da escala Relational Interdependent SelfConstrual: 0 Relational Interdependent Self-construal (RISC) pode ser descrito como o grau em que os indivíduos se definem em termos das suas relações íntimas. Devido à importância deste constructo e da sua medida, a escala RISC, em processos individuais e sociais, realizámos dois estudos de validação da escala para a população Portuguesa. A escala RISC, unidimensional e composta por 11 itens, foi traduzida para o português e as suas propriedades psicométricas foram analisadas com duas amostras: 399 participantes para o estudo 1 (62.9\% mulheres e $30.8 \%$ homens, com idades entre os 18 e os 59 anos - $M$ $=26.4 ; D P=8.90)$ e 292 participantes para o estudo $2(57.9 \%$ mulheres e $42.1 \%$ homens, com idades entre os 17 e os 59 anos $-M=26.37, D P=8.87)$. Os resultados confirmaram a estrutura unidimensional da escala, mostrando bons valores de validade e de ajustamento do modelo ( $\mathrm{CFI}=0.92 ; \mathrm{TLI}=0.87 ; \mathrm{NFI}=$ 0.89; RMSEA $=0.09$ ). A escala RISC-P mostrou ser invariante entre géneros, observando-se que as mulheres apresentam valores mais elevados de RISC. Os bons indicadores psicométricos e de ajustamento do modelo validam o uso desta versão para a população Portuguesa em muitas áreas de investigação (e.g., controlo da desejabilidade social, análise de validade convergente e preditiva).

Palavras-chave: RISC (Relational Interdependent Self-Construal); Escala; Adaptação; Invariância de Género.

With the emergence of cultural psychology in the $90 \mathrm{~s}$, which focused on culture as a collective programming of the mind that differentiates groups and guides social behaviour and thinking (e.g. Kitayama, 2002; Nisbett, 2003; Triandis, 1994), the Hofstede model (1980) has become one of the most popular in the scientific community. Among the dimensions of culture presented by Hofstede (1980), the individualism/collectivism dimension characterises the degree to which individual identity is centred on personal goals and vested interests (the interests of the group of which the individual is a part). In other words, in certain cultures, individuals think and orient their behaviours around their interests and individual responsibility, in contrast to collectivist cultures that guide behaviour as a function of the collectivity. For Markus and Kitayama (1991), self-construal reflects the individualism-collectivism dimension at the level of individual personality. Self-construal is defined as the conception that

${ }^{1}$ Address for correspondence:: Cátia Sousa, Campus de Gambelas, Faculdade de Ciências Humanas e Sociais, Edf.1 8005-139 Faro. E-mail: cavsousa@ualg.pt. This paper is financed by National Funds provided by FCT- Foundation for Science and Technology through project UID/SOC/04020/2013 
individuals have of themselves (Markus \& Kitayama, 1991), one which gives meaning to their life experiences (Baumeister, 1999; Markus, 1977). According to Markus and Kitayama (1991), each person incorporates in her/his self-construal an independent and interdependent dimension, and it is the cultural context in which the individual develops that encourages the development of one dimension over another. That is, self-construal is based on how cultural belief systems result in structural differences in the perception that the individuals have of themselves, affecting their behaviour (Oetzel \& Bolton-Oetzel, 1997). Each cultural context establishes social interactions with different degrees of involvement with other people and, as a result, the self and the way individuals see themselves reflect these cultural differences (Kitayama, Duffy, \& Uchida, 2007; Markus \& Hamedani, 2007; Markus \& Kitayama, 2003; Markus, Mullally \& Kitayama, 1997). For example, identities undergo more changes in collectivist cultures because behaviour is determined according to the major roles and social relations required (Kanagawa, Cross, \& Markus, 2001; Suh, 2002). Another example is the notion of me and myself. The terms me and myself can be understood differently in different cultures. In the United States, where many states have individualistic characteristics (Vandello \& Cohen, 1999), and especially in the upper and upper middle classes, the term self is usually assimilated as something intimate, private, and independent from other individuals and the social context; conversely, in Japan (collectivist society) the self appears associated with the flexibility and openness required in specific social context (Kanagawa, et al., 2001; Markus \& Kitayama, 1991; Sousa, Gonçalves, \& Cunha, 2015). That is, Westerners are characterized by having an independent self-construal and Easterners by an interdependent self-construal (Cross, Erin \& Berna, 2009). However, although these examples serve to illustrate the cultural differences between East and West (individualism/collectivism), the two selves are not incompatible (Markus \& Kitayama, 1991). In general, people have aspects of both selves in their self-definition, as their cultures have individualistic and collectivists elements (e.g. Kagitçibasi, 1994; Kashima et al., 2004; Kim, Kim, Kam, \& Shin, 2003; Singelis \& Brown, 1995). An independent self-construal is defined as a self "delimited, unitary and stable" that is separated from the social context (Singelis, 1994, p. 581). The emphasis is placed on inner qualities, thoughts and feelings of their own. Individuals seek to be unique, independent and invariant in various contexts, promoting their own interests and goals (Markus \& Kitayama, 1991; Singelis, 1994). When they think about themselves and about others, individuals with this type of self-construal have as a reference their skills, internal attributes and characteristics, regardless of social context in which they live, their social roles and their interpersonal relationships (Markus \& Kitayama, 1991; Singelis, 1994). On the other hand, the interdependent self-construal measures the tendency to think of ourselves in terms of our relationships with others (Markus \& Kitayama, 1991). Therefore, to maintain and increase this interdependent view of self, individuals tend to think and behave in ways which emphasise their connection with others and strengthen existing relationships (Cross, Bacon, \& Morris, 2000). In other words, the perception that we have of our own self depends on the relationship we have with the others. This emphasis on the relationship with others in the conception of the own self (Oetzel \& Bolton-Oetzel, 1997) implies shifting the focus of perception from the individual self to the relational self and to the collective self (Sedikides \& Brewer, 2001). Individuals seek to create harmonious relations by adapting to and helping others, in accordance with social rules and cooperative behaviours (Oetzel \& Bolton-Oetzel, 1997). In this respect, Cross et al. (2000) reported that individuals who have high self-interdependent characterise their significant relationships as being closer than do people who have low selfinterdependent. Thus, they are more likely to take into account the needs and desires of the others in decision making.

Self-construal construct has been related to multiple variables, such as affirmative action attitudes (Ozawa, Crosby, \& Crosby, 1996), compassionate goals (Jianga, Canevello, Gore, Hahn \& Crocker, 2017), career development (Hardin, Leong, \& Osipow, 2001), the communication process (Singelis \& Brown, 1995), self-esteem (Sato \& Cameron, 1999), feelings of embarrassment (Singelis \& Sharkey, 1995; Singelis, Bond, Sharkey, \& Lai, 1999; Gouveia, Singelis, War, Santos, \& Vasconcelos, 2006), morality (Cohen \& Rozin, 2001), biculturalism (Yamada \& Singelis, 1999), welfare (Cross, Gore, \& Morris, 2003), life satisfaction (Heintzelman \& Bacon, 2015), sociocultural adjustment (Cross, 1995; Oguri \& Gudykunst, 2002) and creativity (Jin, Wang, \& Dong, 2016), among others.

\section{Relational Self-Construal and Gender}

Several studies have allowed us to observe differences between the interdependence and independence, in particular with regard to gender (e.g., Armas, Gómez, Hernandéz, Galind, \& Asensio, 2014; Cross et al., 2000; Cross \& Madson, 1997; Gabriel \& Gardner, 1999). For example, Cross and Madson (1997) found that while women tend to describe themselves in terms of relationships with others, men tend to selfdescribe in terms of separation from others (e.g., Pratt, Prancer, Hunsberger, \& Manchester, 1990). This situation can be illustrated in terms of conversational preferences, i.e., women prefer to talk about 
relationships while men prefer to discuss less personal topics such as sports and politics (e.g., Aries \& Johnson, 1983; Cross \& Madson, 1997). Moreover, women tend to evaluate themselves more favourably in self-related dimensions related to interdependence, whereas men self-evaluate themselves more favourably in independent dimensions (e.g., Zuckerman, 1985). To Cross et al. (2000), the specific characteristics of interdependent self-construal developed by members of individualist and collectivist societies vary according to their cultural differences and across gender.

In this regard, some studies show that in Western cultures (characterised as individualistic and therefore favouring independent self-construal) women are more likely than men to incorporate intimate relationships in their self-construal (e.g., Cross \& Madson, 1997). These results show that the interdependent self-construal can be defined in terms of the interdependence of intimate relationships (close friends, siblings, spouse) and the interdependence of collective relations (relative to group members), thus distinguishing the "self-construal relational-interdependent" from the "collectiveinterdependent self-construal". In this respect, Baumeister and Sommer (1997) argue that there are no gender differences between interdependence and independence. For the authors, gender differences are internal to interdependence, with women being more relational interdependent and men more collective interdependent (Baumeister \& Sommer, 1997). These two forms of interdependence were identified as the relational self and the collective self (Sedikides \& Brewer, 2001).

\section{Self-Construal Concepts and Measures}

The relationship that the self-construal has with these cognitive, emotional and motivational processes (cf. Cross, Hardin, \& Gercek-Swing, 2009) and others has motivated an increasing interest in the dimensions of self-construal (independent, relational and collective-interdependent). Table 1 presents a summary of these concepts and corresponding measures.

Table 1. Summary of the concepts and measures of Self-Construal.

\begin{tabular}{|c|c|c|c|}
\hline Authors & Concept & Definition & Measures \\
\hline Markus \& Kitayama (1991) & Self-Construal & $\begin{array}{l}\text { How individuals define and } \\
\text { make meaning of the self and } \\
\text { how individuals see the self in } \\
\text { relation to others. The self is } \\
\text { characterized as independent } \\
\text { or interdependent. }\end{array}$ & $\begin{array}{l}\text { Self-Construal Scale (SCS) - } \\
\text { Singelis (1994); } \\
\text { Self-Construal - Gudykunst et al. } \\
\text { (1996); } \\
\text { Revised SCS - Leung \& Kim } \\
\text { (1997). }\end{array}$ \\
\hline Andersen \& Chen, (2002) & Relational Self & $\begin{array}{l}\text { Individuals possess multiple } \\
\text { selves in relation to the various } \\
\text { significant others in their lives, } \\
\text { each linked in memory with a } \\
\text { particular significant other. }\end{array}$ & - \\
\hline Cross et al. (2000) & $\begin{array}{l}\text { Relational-Interdependent } \\
\text { Self-Construal }\end{array}$ & $\begin{array}{l}\text { Characterized by the extent to } \\
\text { which one defines the self in } \\
\text { terms of close relationships. }\end{array}$ & RISC. \\
\hline $\begin{array}{l}\text { Cross et al. (2000); } \\
\text { Kashima \& Hardie (2000) }\end{array}$ & $\begin{array}{l}\text { Collective-Interdependent } \\
\text { Self-Construals }\end{array}$ & $\begin{array}{l}\text { Corresponds to the degree to } \\
\text { which the person defines the } \\
\text { self in terms of social groups or } \\
\text { larger collectives. }\end{array}$ & $\begin{array}{l}\text { Conjunction of various scales: } \\
\text { Self-Construal Scale (SCS), } \\
\text { Relational Interdependent Self- } \\
\text { Construal (RISC), and Twenty } \\
\text { Statements Test (TST). }\end{array}$ \\
\hline
\end{tabular}

As we can see, the self-construal construct is associated with the specific dimensions of selfdefinition. Furthermore, the collective self-interdependent construal and relational interdependent selfconstrual $^{2}$ (RISC) relate to the degree to which the relationship with the others is integrated in the selfdefinition. The first is focused on the social groups to which we belong (Markus \& Kitayma, 1991; Triandis, 1989) (for example: I am Portuguese; I am a doctor), whereas RISC is focused on the other with whom I have a close (intimate) relationship (for example: I'm a friend of ...; I'm a mother of ...) which may constitute a dyadic relationship (cf., Cross, 2009).

The RISC provides a cognitive framework for regulating emotion, cognition (cognitive processes) and motivation where the connection between an individual and others is evident in their selfrepresentation (Cross \& Madson, 1997; Gelfand, Major, Raver, Nishii, \& O’Brien, 2006). Consequently, the

\footnotetext{
${ }^{2}$ In abbreviated form: Relational Self-Construal (in Cross, 2009, p. 950). Cross and Madson (1997) propose another name for the relational interdependent self-construal - "model".
} 
RISC promotes three cognitive processes (Cross et al., 2000). Relational cognition, which refers to the notion that the connection of an individual is the main focus of awareness which leads to the perception of the behaviours of the other. This attention to the relational information fosters acceptance of the perspectives of the others, facilitating relational harmony. The second process is emotional in nature. The relational emotion works to obtain and experience emotions: connection to others becomes a major source of positive emotion and self-esteem; disconnection from others can trigger anxiety or distress. The third process is the relational motivation, which that serves to regulate encounters through targeted goals and involves the analysis of an individual's actions, based on the feelings and needs of others (Cross et al., 2000; Gelfand et al., 2006).

Cross et al. (2000) propose a one-dimensional scale (Relational-Interdependent Self-Construal Scale, RISC) to measure the relational aspect of the interdependent dimension. In general individuals with high scores on this scale take into account the views and needs of others in decision-making processes, are more open and interact more easily with others (Cross et al., 2000). The RISC scale shows good reliability values (between 0.85 and 0.90 ), test-retest stability and other psychometric indices (see Cross et al., 2000). Several studies have shown that the RISC scale has high positive and moderated correlations with the Communal Orientation Scale of Clark, Ouellette, Powell and Millberg (1987), Interdependent Self-Construal Scale of Singelis (1994), Empathic Concern Scale of the Interpersonal Reactivity of Davis (1980), and NEO-FFI (agreeableness and extraversion factors) (Cross et al., 2000), as well as with the Twenty Statement Test of Kuhn and McPartland (1954) (e.g. Bresnahan et al., 2005; Gardner, Gabriel, \& Lee, 1999) and the Basic Need Satisfaction in General of Deci and Ryan (2000, 2002) (Armas et al., 2014), among others. The significance of RISC in social behaviour, particularly in relation to friendship and in intimate relationships (e.g., Boucher, 2014; Butcher \& Gore, 2012; Cross et al., 2000; Gore, Cross, \& Morris, 2006), citizenship behaviours (Petrella \& Gore, 2013), personality and personal interests (e.g. Armas et al., 2014; Cross et al., 2000), social support and life satisfaction (Heintzelman \& Bacon, 2015) attitudes and behaviours in response to charity advertisements (Burton, Gore, \& Sturgeon, 2012), adjustment capacity to social contexts (e.g. academic context, Rahat \& Ílhan, 2016), among others, has contributed to the growing research on the construct and its validation for different populations. To our knowledge, RISC scale has been adapted for the Korean and Japanese (Bresnahan et al., 2005), Spanish (Armas et al., 2014), Turkish (Akın, Eroğlu, Kayıș, \& Satıcı, 2010) populations, presenting acceptable values of internal consistency in each case (0.68 to 0.85 ).

Given the importance of this concept, our goal in the first study is to adapt the RISC scale developed by Cross et al. (2000) to the Portuguese population and validate it, specifically through construct validity and internal consistency. Given the vast amount of literature which supports the thesis of gender differences in cognitive processes, motivation, emotional and social behaviour, and in particular, the evidence relating to gender differences in forms of self-construal, we conducted a second study. In this study we performed an additional psychometric assessment of the RISC scale by examining the equivalence of measuring gender (invariance analysis) and a means comparison ( $t$-test) between genders, and, based on the prior literature, it is our expectation that women would exhibit significantly higher results than men.

\section{STUDY 1}

Study 1 aims to analyse the psychometric properties of the RISC scale, through an exploratory (EFA) and confirmatory (CFA) factor analysis and a reliability analysis.

\section{Method \\ Participants}

The study sample consists of 399 participants, and no outliers have been detected. About $62.9 \%$ of the participants are women and $30.8 \%$ are men, aged between 18 and 59 years $(M=26.4 ; S D=8.90)$. With regard to qualifications, participants are mostly graduates (46.9\%). Most respondents are single $(75.1 \%)$ and students (50.7\%).

\section{Instruments}

Relational Interdependent Self-Construal Scale (RISC). This tool, originally developed by Cross et al. (2000) consists of 11 items assessed on a Likert scale from 1 (Strongly Disagree) to 7 (Strongly Agree). It is an instrument that seeks to assess the degree to which the individuals include their intimate relationships in their self-concept (e.g. item 2: "When I feel very close to someone, it often feels to me like that person is an important part of who I am"; item 5: "When I think of myself, I often think of my close friends or family also"). In the original study (Cross et al., 2000) results based on eight samples had a Cronbach's alpha 
ranging between 0.85 and 0.90 . The use of the RISC scale in this study was authorized and approved by the original authors (Cross et al., 2000).

Demographics. In order to characterize the sample participants were asked to provide basic demographic information, including gender, age, marital status and educational level.

\section{Procedure}

Upon approval by the Scientific Committee (the entity responsible for monitoring the procedures and ethical safeguards of research) and assurance of ethical criteria (e.g. provision of information about the voluntary and anonymous nature of the study), participants were asked to answer a self-report questionnaire with an average completion time of 15 minutes. The questionnaire was completed in a single session. Data collection was performed in several places, collectively and individually, namely in university classes, public and private companies, public libraries, and other public places. No compensation was offered to participants. The study subject was blinded and after the collection a debriefing was carried out. Only questionnaires that were completed correctly were considered. This procedure was used for studies one and two.

Apparent validity was supported through a back translation process in accordance with Hambleton, Merenda, and Spielberger's procedure (2006). First, the scale was translated from English into Portuguese by two bilingual specialists working independently. Subsequently, both versions were retranslated into English by two other bilingual specialists, also working independently. The translations were compared to the original and adjusted by three psychologists expert in this theme. Finally, an expert panel of faculty members from the University validated the questionnaire in terms of its content, format, sequence and layout. Originally items 8 and 9 were reversed. However, in this study item 9 was transformed into a positive item to avoid double negatives and thus to facilitate their understanding. Like other measure validation studies, the Portuguese versions tend to avoid items with double negative as they make the interpretation more complex, this aspect is evident in the amount of low factor loadings (e.g. Ambivalent Sexism Inventory in Glick et al., 2000). The definition of a "close person" was provided as a guideline in the questionnaire, "the person who is part of the personal relationships of the individual, with whom he/she has a strong connection. That's to say, it is the person with whom we have a strong relationship, not necessarily love. It includes loving relationship with close friends, family, etc.". To test the translation, 10 participants were asked to answer the Portuguese version (pre-test), in order to correct possible semantic problems. In this pre-test no interpretation problems were detected. These participants were not included in the final sample.

\section{Data analysis}

The data analysis was performed using the SPSS 22 statistical package and AMOS 20 software and the significance level was set at 0.05 . it was considered the probability of significance at the level of 0.05 since this $p$ value is the most frequently used criterion for a decision on statistical inference (Marôco, 2011). The psychometric properties of the RISC scale were evaluated by exploratory, confirmatory factorial analysis and internal consistency. To analyse the cross validity, the samples were randomly divided into two parts (Worthington \& Whittaker, 2006): 200 participants to the exploratory analysis and 199 participants to the confirmatory analysis. To verify construct validity, the RISC scale was submitted to an exploratory factor analysis validated by KMO criteria and the factors extraction was validated by the method of the principal components. Internal consistency was assessed by Cronbach's alpha which can vary on a scale from 0 to 1 , assuming values from 0.70 as acceptable (Nunnally, 1978).

\section{Results \\ Descriptive analysis of the RISC Items}

Through Table 2 it is possible to observe the mean scores, standard deviations, and corrected item-total correlation and Cronbach's alpha if item deleted. The items' means vary between 5.87 (item 6) and 3.29 (item 8). In terms of the corrected item-total correlation ( $\alpha$ ranges from 0.71 to -0.29 ), only item 8 is below 0.30 (and negative) (Nunnally \& Bernstein, 1994). Also, it is worth noting that the withdrawal of item 8 increases Cronbach's alpha to 0.90. Measures of skewness and kurtosis showed that the distributions of the 11 RISC scale items were normal (skewness from -1.27 to 0.33 and kurtosis from 1.11 to 2.04), since they are below 2 and 7 respectively (Bentler \& Wu, 2002; Curran, West, \& Finch, 1996; Finney \& Distefano, 2006; West, Finch, \& Curran, 1995). All items explained a substantial amount of variance, except for item 8 ( $R^{2}$ ranged from 0.15 to 0.56$)$. 
Table 2. Descriptive statistics of items $(n=399)$.

\begin{tabular}{|c|c|c|c|c|c|c|c|}
\hline Item & M & SD & $\begin{array}{c}\text { Corrected } \\
\text { item-total } \\
\text { correlation }\end{array}$ & $\begin{array}{l}\text { Cronbach's } \\
\text { alpha }(\alpha) \text { if } \\
\text { item deleted }\end{array}$ & $\begin{array}{c}\text { Sk } \\
S E=0.17\end{array}$ & $\begin{array}{c}\mathrm{Ku} \\
S E=0.34\end{array}$ & $R^{2}$ \\
\hline 1 & 5.79 & 1.13 & 0.67 & 0.81 & -0.87 & 0.36 & 0.51 \\
\hline 2 & 5.59 & 1.32 & 0.71 & 0.80 & -1.07 & 0.96 & 0.56 \\
\hline 3 & 6.46 & 0.78 & 0.48 & 0.82 & -1.27 & 0.67 & 0.37 \\
\hline 4 & 5.55 & 1.25 & 0.65 & 0.81 & -1.19 & 2.04 & 0.49 \\
\hline 5 & 516 & 1.49 & 0.68 & 0.80 & -0.75 & -0.02 & 0.54 \\
\hline 6 & 5.87 & 1.65 & 0.61 & 0.81 & -1.12 & 1.02 & 0.49 \\
\hline 7 & 5.09 & 1.41 & 0.62 & 0.81 & -0.57 & -1.11 & 0.53 \\
\hline 8 & 3.29 & 1.70 & -0.29 & 0.90 & 0.33 & -1.07 & 0.15 \\
\hline 9 & 5.08 & 1.41 & 0.65 & 0.80 & -0.66 & 0.04 & 0.55 \\
\hline 10 & 5.81 & 1.24 & 0.59 & 0.81 & -1.26 & 1.68 & 0.45 \\
\hline 11 & 5.68 & 1.17 & 0.68 & 0.80 & -0.91 & 0.59 & 0.51 \\
\hline \multicolumn{8}{|c|}{$\alpha=0.84$} \\
\hline
\end{tabular}

\section{Exploratory factor analysis}

In order to examine the structure of the RISC scale, an exploratory analysis was performed. The KMO index showed a value of 0.908 (Bartlett sphericity test $=1016.420 ; d f=55 ; p<0.001$ ).

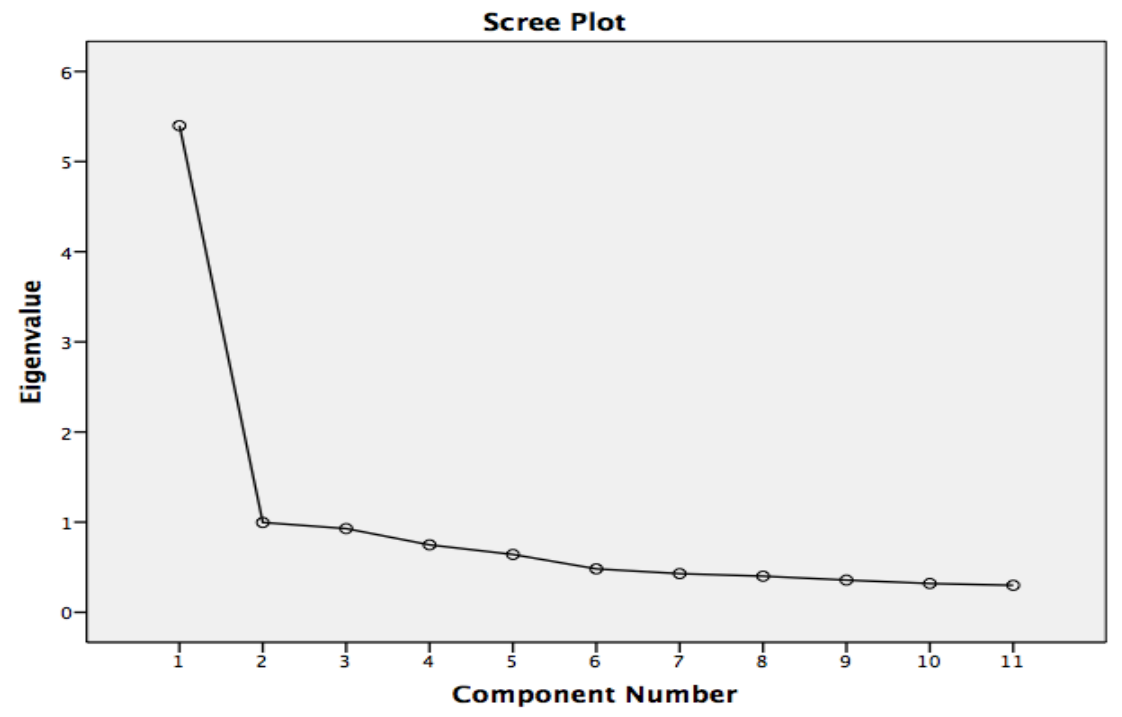

Figure 1. RISC scale items Scree Plot

The principal component analysis, considering the criteria of eigenvalues greater than 1 for the determination of the factors to retain, allowed us to observe one factor (Figure 1), which explain 49.10\% of the total variance of the results obtained (Table 3), thus replicating the original, one-dimensional structure of the scale.

Given the results, we decided to remove item 8 from the final scale and then performed a new analysis. The KMO index increased slightly (0.91) as well as the Bartlett test $\left(X^{2}(45)=985.14 ; p<0.001\right)$. The new factorisation holds the one-dimensional structure with a factor that explains about $52.99 \%$ of the total variance and factorial weights ranging from 0.58 (item 3) to 0.79 (item 2). Without item 8 the scale has an internal consistency index of 0.90 . 
Table 3. Main components extracted from WFGS (communalities and factor weights).

\begin{tabular}{|c|c|c|}
\hline & Factor 1 & Communalities \\
\hline Item 2 & 0.79 & 0.63 \\
\hline Item 5 & 0.77 & 0.59 \\
\hline Item 7 & 0.75 & 0.56 \\
\hline Item 1 & 0.75 & 0.56 \\
\hline Item 9 & 0.74 & 0.54 \\
\hline Item 4 & 0.74 & 0.54 \\
\hline Item 11 & 0.74 & 0.55 \\
\hline Item 6 & 0.72 & 0.52 \\
\hline Item 10 & 0.67 & 0.45 \\
\hline Item 3 & 0.58 & 0.33 \\
\hline Item 8 & -0.35 & 0.12 \\
\hline Eingenvalue & \multirow{2}{*}{\multicolumn{2}{|c|}{$\begin{array}{c}5.39 \\
49.10 \%\end{array}$}} \\
\hline Variance & & \\
\hline
\end{tabular}

\section{Confirmatory Factor Analysis}

The 11 items of the RISC scale were submitted to a confirmatory factor analysis (CFA) adopting the maximum likelihood estimate (ML). The adjustment values were: $X^{2}{ }_{(44)}=13.81$ which results in a CMIN/DF of 2.99, this value being a good indicator (Byrne, 2001). The CFI (0.91), NFI (0.87) and TLI (0.87) values are close to the value 1, which shows an acceptable adjustment (Bentler, 1990; Byrne, 2001; Marôco, 2011). The RMSEA value (0.09) is also within the acceptable adjustment range (Hu \& Bentler, 1999; Ullman, 2006). However, models with small samples and low degrees of freedom can have artificially large values of RMSEA (Kenny, Kaniskan, \& McCoach, 2015).

Given the results obtained in the exploratory analysis, we tested a second model from which item 8 had been removed. The adjustment values experienced a slight improvement, particularly CFI (0.92) and NFI (0.89), as can be seen in Table 4.

Table 4. Goodness-of-fit indices of the RISC scale.

\begin{tabular}{lcccccccc}
\hline & $\mathbf{N}$ & $\boldsymbol{\chi 2}$ & df & CMIN & CFI & RMSEA & TLI & NFI \\
\hline RISC - 11 items & 199 & 131.81 & 44 & 2.99 & 0.91 & 0.09 & 0.87 & 0.87 \\
RISC - 10 items & 199 & 115.91 & 35 & 3.31 & 0.92 & 0.09 & 0.87 & 0.89 \\
Spanish version & 216 & 26.346 & 24 & 1.1 & 0.98 & 0.02 & 0.97 & - \\
\hline
\end{tabular}

Considering the results obtained in the factorial analysis and internal consistency, we considered it appropriate to remove item 8 from all subsequent analyses. The new version of the scale, with 10 items and translated into Portuguese, will be renamed RISC-P (see Appendix).

\section{STUDY 2}

The literature presents two corollary predictions regarding women being more relational interdependent (e.g., Gabriel \& Gardner, 1999; Kashima \& Hardie, 2000), and men more collective-interdependent (e.g., Gabriel \& Gardner, 1999). Therefore, the purpose of Study 2 is to analyse the RISC-P scale measurement invariance across gender and the differences between men and women with respect to the levels of RISC. It is our expectation that women have a higher degree of relational self-construal than men.

\section{Method}

Sample

The sample consists of 292 participants and no outliers have been detected. About $57.9 \%$ are women and $42.1 \%$ are men $\left(M_{\text {age }}=26.37 ; S D=8.87\right.$; range $\left.=17-59\right)$. About $47.6 \%$ of the participants have a university degree. Most respondents are single (80.1\%) and students (53.4\%).

\section{Measures}

The RISC-P scale previously referred and translated into Portuguese was used. As a result of the exploratory and confirmatory analyses performed in the previous study, item 8 was withdrawn and the one-dimensional structure of the scale was replicated, with good levels of adjustment and good internal consistency $(\alpha \geq 0.90)$.

Besides the scale, further items relating to biographical characteristics (age, marital status and educational level) were added, in order to allow sample characterization. 


\section{Data analysis}

To evaluate the adjustment between the data and the model, a number of indexes are referenced. Hu and Bentler (1999) recommended the following fit indexes be considered in model fit assessment: the comparative fit index (CFI), Tucker-Lewis Index (TLI) and root mean square error of approximation (RMSEA). The CFA model, which was developed in our previous study, was used as a baseline model and it was fitted to the data from each gender group (see Figure 2).

\section{Results}

\section{Measure invariance across gender}

To analyse the measure invariance across gender, we used a multi-group confirmatory factor analysis adopting the maximum likelihood estimate (ML). Multivariate normality was assessed through skewness (between -0.060 and -1.44), kurtosis (between 0.003 and 1.87) and multivariate kurtosis (0.207). Prior to any invariance analysis, the model was applied by gender. For the male group $(\chi 2(70)=159.28, p<$ $.0001 ; \mathrm{CFI}=0.94 ; \mathrm{TLI}=0.92 ; \mathrm{NFI}=0.89 ; \mathrm{RMSEA}=0.06)$ and for the female group $(\chi 2(70)=159.28, \mathrm{p}<$ $.0001 ; \mathrm{CFI}=0.94 ; \mathrm{TLI}=0.92 ; \mathrm{NFI}=0.89 ; \mathrm{RMSEA}=0.06$ ) the fit values were equal, acceptable and presenting the same factorial structure in both groups (configurational invariance) (Marôco, 2014). Figure 2 shows the estimates of the factor weights and individual reliability of the items in the model for the women and the men.
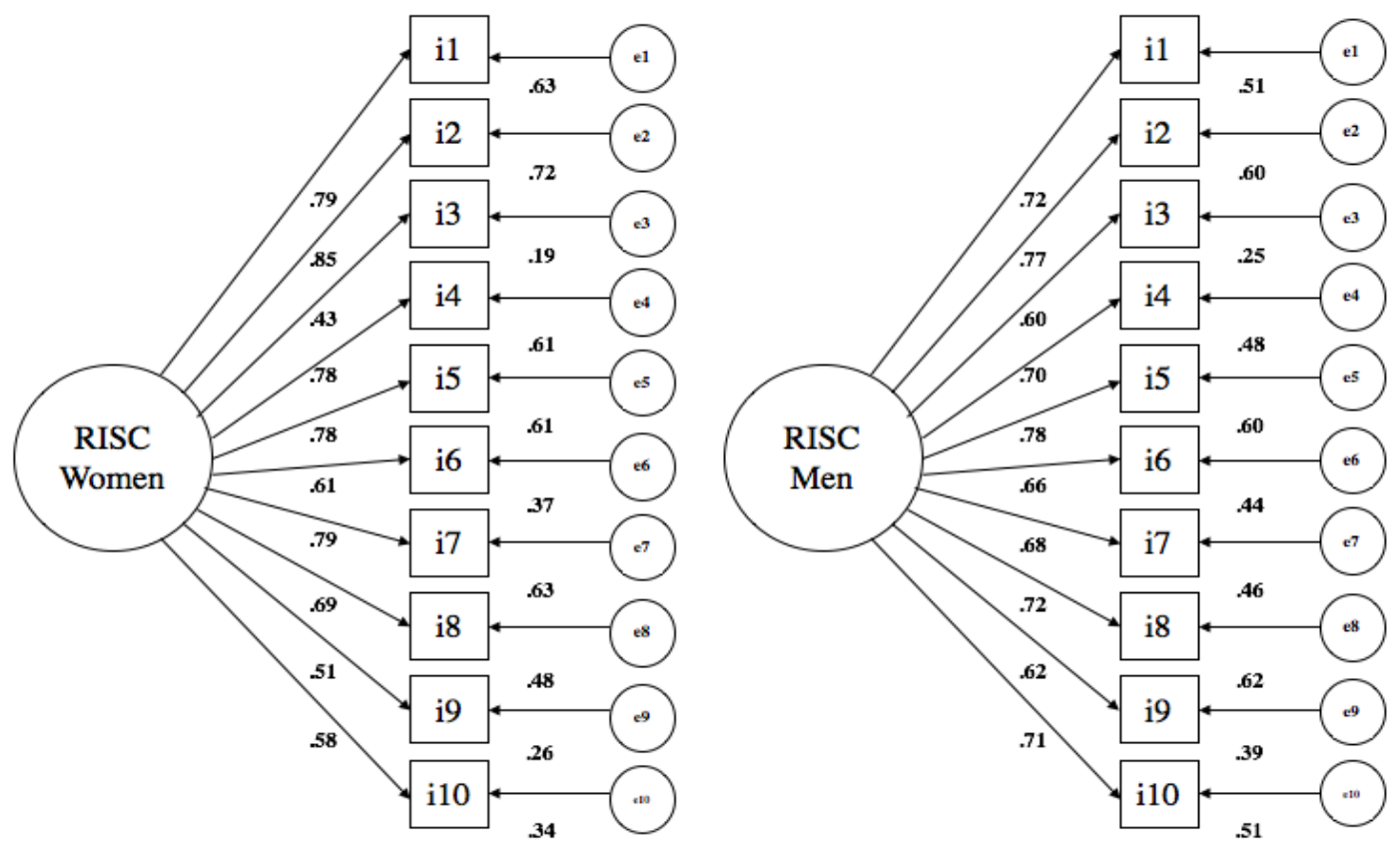

Figure 2. Model of the RISC scale FCA: women $(n=169)$ and men $(n=123)$ samples

First, a multi-sample analysis with the unconstrained model showed an acceptable baseline model (configurational invariance) for both men and women $(\chi 2(70)=159.29, \mathrm{CMIN} / d f=2.28, p<.0001 ; \mathrm{NFI}=$ 0.89; CFI $=0.94 ;$ TLI $=0.92 ;$ RMSEA $=0.06$ ). Assuming the unconstrained model, we then assessed measurement weights and structural covariance by nesting the models and increasing constraints. The comparison of the unconstrained model with the measurement weights model (metric model) show no significant differences $\left(d f=9\right.$; CMIN $\left.\left(\chi 2_{\text {diff }}\right)=11.17, p=0.264\right)$ thus demonstrating the invariance of the factor weights in both groups. The comparison of the unconstrained model with the measurement intercepts model (scalar model) show no significant differences $\left(d f=19\right.$; $\left.\operatorname{CMIN}\left(\chi 2_{d i f f}\right)=26.84, p=0.108\right)$ thus demonstrating the scalar invariance in both groups. As regards the comparison of the unconstrained model with the adjustment of the structural covariance model $\left(d f=20\right.$; $\left.\operatorname{CMIN}\left(\chi 2_{\text {diff }}\right)=26.92, p=0.137\right)$ it demonstrates the factorial invariance of the scale for men and women (Table 5). That is, the results show that men and women do not differ in how they interpret the RISC construct, thus providing support for the use of this instrument in comparative studies and reinforcing the quality of the examined version. 
Table 5. Models fit indexes.

\begin{tabular}{|c|c|c|c|c|c|c|c|}
\hline Models & $\chi 2$ & Df & CMIN & CFI & RMSEA & TLI & NFI \\
\hline Unconstrained (configurational) & 159.29 & 70 & 2.28 & 0.94 & 0.06 & 0.92 & 0.89 \\
\hline Measurement Weights (metric) & 170.46 & 79 & 2.16 & 0.93 & 0.06 & 0.92 & 0.88 \\
\hline Measurement Intercepts (scalar) & 186.13 & 89 & 2.09 & 0.93 & 0.06 & 0.93 & 0.87 \\
\hline Structural Covariance & 186.21 & 90 & 2.07 & 0.93 & 0.06 & 0.93 & 0.87 \\
\hline
\end{tabular}

\section{Gender Differences}

An independent samples t-test was conducted to examine whether there was a significant difference between women and men in relation to their RISC. The results show that it is women who have a higher RISC mean compared to men $\left(\mathrm{M}_{\text {Women }}=5.42, S D=0.76\right.$ and $\left.\mathrm{M}_{\mathrm{Men}}=5.19, S D=0.75\right)$. According to the Student's $\mathrm{t}$-test the differences observed in the two groups are statistically significant $\left(\mathrm{t}_{(397)}=-2.52 ; p=\right.$ $0.012)$, though the effect size is small $(d=.25)$. This result is consistent with many authors' investigations (e.g. Cross et al., 2000; Cross \& Madson, 1997; Cross, Morris, \& Gore, 2002; Gabriel \& Gardner, 1999).

\section{DISCUSSION}

In a broad sense, we can define relational interdependent self-construal as the degree to which individuals define themselves in terms of their intimate relationships (Cross, 2009). Given the importance that this construct and the resulting measure have in relation to individual and social processes, we conducted two studies in order to validate the RISC scale for the Portuguese population. The results indicate a good reliability of the adaptation of the scale to the Portuguese culture. The first study focused on the construct validity (for which exploratory, confirmatory factor analysis was conducted) and the internal consistency of the scale. The exploratory analysis showed good values of validity and good psychometric properties, similar to the original study. It also confirmed its one-dimensionality. Item 8 in their original version ("Overall, my close relationships have very little to do with how I feel about myself") revealed low factor loading, affecting the psychometric indicators. Therefore, we propose that the Portuguese version does not include this item, leaving the RISC scale with 10 items instead of the initial 11 items. Internal consistency values are good and similar to the original study (Cross et al., 2000) and other adaptations (e.g. Armas et al., 2014; Bresnahan et al., 2005). Confirmatory analysis showed a good fit of the model proposed by Cross et al. (2000); it should be noted that the withdrawal of item 8 does not significantly affect the model adjustment indexes. In the second study, it was possible to confirm the factorial invariance of the scale for both genders, which, on the one hand, provides additional support for the use of this instrument in comparative studies and, on the other, reinforces the quality of the version proposed. Supporting the findings of the literature mentioned above, we observed differences between genders (e.g. Armas et al., 2014; Cross et al., 2000), since women have higher RISC means than men. That is, in defining the self, women give more weight to others (close relationships) than men do. Although significant, the differences found between genders may not be considered too high. This situation may be related to the culture factor. Studies have shown that Western cultures, being more individualistic, exhibit gender differences (relational interdependent) (e.g., Cross \& Madson, 1997). According to some studies, Portugal has been considered a collectivist country (e.g., Hofstede), due to the homogeneity of its culture (e.g., Neto, 1995), and to a political regime that only 40 years ago ceased to be totalitarian, paternalistic and family-centered and with a tendency towards cohesion between individuals and groups, be they family members or professionals. In this sense, it would be expected that there were no differences between genders. However, these exist. This means that Portugal, by virtue of a series of events (e.g., establishment of the democratic regime, economic benefits, accession to the European Community), began to assimilate the norms of the individualist life model (Ciochină \& Faria, 2006). The change from collectivism to individualism is, in fact, a trend that has been observed in many countries characterized by a framework of economic enrichment (Ciochină \& Faria, 2006; Triandis, McCusker, \& Hui, 1990). Thus, with this gradual approach to individualism, especially in younger generations (e.g., Ciochină \& Faria, 2009), it is expected that gender differences in relational interdependent self-construal become more salient over time.

\section{Limitations and suggestions for future studies}

Although the sample, taking into account the scale validation goal, exceed 10 participants per item (Watkins, 1989), we consider that the number of participants prevents the generalisation of the results to the entire Portuguese population. The homogeneity of the sample may also be a limiting factor because about $50 \%$ of the participants are students, though some authors state that there are no broad differences between students and adults, or between age and occupation (e.g. Gibas, Giraud, Conte, Martin, \& Isableu, 2016; Levine et al., 2003; Oyserman, Coon, \& Kemmelmeier, 2002). Furthermore, the unequal gender 
distribution may have had some influence on the results obtained. Therefore, it is important that more gender-balanced samples are obtained in future studies. Additional studies should be conducted with more diverse populations, varying in age, socio-professional background and ethnicity to apprehend the self-construal of a larger range of the Portuguese population. However, it should be emphasised that the good psychometric indicators and model adjustment of this version of the scale validates its use for the Portuguese population in many research settings. Further studies should explore complementary psychometric indicators (test-retest) and the control of social desirability effect, as well as analysing convergent validity (e.g. Communal Orientation Scale of Clark et al., 1987). As in other studies, predictive validity can be analysed in relation to communication styles, helping behaviour and adjustment capacity. Analysis of the relation with similar variables (e.g. Leung \& Kim, 1997; Gudykunst et al., 1996; Singelis, 1994) will enable observation of other psychometric indicators, in particular, the convergent validity, as well as supporting the cultural perspective of the self in the Portuguese population. Finally, the application of measures for an analysis of individualism/collectivism in Portugal (e.g. Hui \& Yee, 1994) would be of immense value, since the literature on this topic focuses mainly on the studies of Hofstede (1980).

\section{CONCLUSION}

The RISC scale developed by Cross et al. (2002) is intended to measure the relational-interdependent self; it has multiple applications in the understanding of human behaviour, and is therefore of great importance for several areas of psychology. For example, RISC scale allows a better understanding of behaviours such as communication (e.g. Singelis \& Brown, 1995), conflict management (e.g., Lu, Fung, \& Doosje, 2017), social relationships and relationships within social networks such as Facebook (Chang, 2015) and even addiction behaviours such as tobacco consumption (Fifita, Smith, \& Fernandez, 2015) or financial and social risk taking (e.g., Mandel, 2003). Relational interdependent self-construal is an important dimension of gender differences (Maddux \& Brewer, 2005; Kashima et al., 1995) and is useful, for example, for understanding social-evaluative concerns (Russel, Gould, \& Fergus, 2017). Thus, the importance of this instrument is evident, and it can be designated as a valid and reliable instrument for the Portuguese population which could be used in several fields, such as, psychology, education or organizational behaviour.

\section{REFERENCES}

Akın, A., Eroğlu, Y., Kayıș, A., \& Satıcı, S. (2010). The validity and reliability of the Turkish version of the relational-interdependent self-construal Scale. Procedia - Social and Behavioral Sciences, 5, 579584. http://dx.doi.org/10.1016/j.sbspro.2010.07.145

Andersen, S., \& Chen, S. (2002). The relational self: An interpersonal social-cognitive theory. Psychological Review, 109, 619-645. http://dx.doi.org/10.1037/0033-295X.109.4.619

Aries, E., \& Johnson, F. (1983). Close friendships in adulthood: Conversational content between same-sex friends. Sex Roles, 9, 1183-1196. https://doi.org/10.1007/BF00303101

Armas, E., Gómez, J., Hernández, H., Galindo, M., \& Asensio, A. (2014). Relaciones entre el autoconcepto relacional, la elección de metas y la satisfacción de necesidades psicológicas en estudiantes $\begin{array}{llll}\text { universitarios. } & \text { Universitas } & \text { Psychologica, } & 13(4),\end{array}$ http://dx.doi.org/10.11144/Javeriana.UPSY13-4.rarm

Baumeister, R. (1999). The nature and structure of the self: An overview. In R. Baumeister (Ed.), The self in social psychology (pp. 1-20). Philadelphia, PA: Psychology Press.

Baumeister, R., \& Sommer, K. (1997). What do men want? Gender differences and two spheres of belongingness: Comment on Cross and Madson. Psychological Bulletin, 122, 38-44. http://dx.doi.org/10.1037/0033-2909.122.1.38

Bentler, P. (1990). Comparative fit indexes in structural models. Psychol Bull. 107(2), 238-46. http://dx.doi.org/10.1037/0033-2909.107.2.238

Bentler, P., \& Wu, E. (2002). EQS for Windows user's guide. Encino, CA: Multivariate Software, Inc.

Boucher, H. (2014). The relational-interdependent self-construal and positive illusions in friendship. Self and Identity, 13(4), 460-476. http://dx.doi.org/10.1080/15298868.2013.843472

Bresnahan, M., Levine, T., Shearman, S., Lee, S., Park, C.-Y., \& Kiyomiya, T. (2005). A multimethod multitrait validity assessment of self-construal in Japan, Korea, and the United States. Human Communication Research, 31(1), 33-59. http://dx.doi.org/10.1093/hcr/31.1.33

Burton, K., Gore, J., \& Sturgeon, J. (2012). The role of relational self-construal in reactions to charity $\begin{array}{lllll}\text { advertisements. Self } \quad \text { Identity, } & \text { 343-359. }\end{array}$ http://dx.doi.org/10.1080/15298868.2011.583529 
Butcher, S., \& Gore, J. (2012). Relational self-construal and the process of forming new relationships. Undergraduate Research Journal for the Human Sciences, 11. Retrieved from: http://works.bepress.com/jonathangore/14

Byrne, B. (2001). Structural equation modeling with AMOS: Basic concepts, applications, and programming. Mahwah, NJ: Lawrence Erlbaum Associates.

Chang, C. (2015). Self-construal and Facebook activities: Exploring differences in social interaction orientation. Computers in Human Behavior, 53, 91-101. https://doi.org/10.1016/j.chb.2015.06.049

Ciochină, L., \& Faria, L. (2006). Individualismo e colectivismo: fundamentos conceptuais para o estudo intercultural das concepções pessoais de inteligência de estudantes portugueses e romenos [Individualism and collectivism: conceptual fundamentals for the intercultural study of personal conceptions of intelligence of Portuguese and Romanian students]. Psicologia, 20(2), 143-165. http://dx.doi.org/10.17575/rpsicol.v20i2.392

Ciochină, L., \& Faria, L. (2009). Individualism and Collectivism: What Differences between Portuguese and Romanian Adolescents? The Spanish Journal of Psychology, 12(2), 555-564. http://dx.doi.org/10.1017/S113874160000192X

Clark, M., Oullette, R., Powell, M., \& Milberg, S. (1987). Recipient's mood, relationship type, and helping. Journal of Personality and Social Psychology, 53(1), 94-103. http://dx.doi.org/10.1037//00223514.53.1.94

Cohen, A., \& Rozin, P. (2001). Religion and the morality of mentality. Journal of Personality and Social Psychology, 81, 697-710. http://dx.doi.org/10.1037//0022-3514.81.4.697

Cross, S. (1995). Self-construals, coping, and stress in cross-cultural adaptation. Journal of Cross-Cultural Psychology, 26(6), 673-697. https://doi.org/10.1177/002202219502600610

Cross, S. (2009). Relational self-construal: Past and future. Social and Personality Psychology Compass, 3(6), 949-961. http://dx.doi.org/10.1111/j.1751-9004.2009.00223.x

Cross, S., \& Madson, L. (1997). Models of the self: Self-construals and gender. Psychological Bulletin, 122, 5-37. http://dx.doi.org/10.1037/0033-2909.122.1.5

Cross, S., Bacon, P., \& Morris, M. (2000). The relational-interdependent self-construal and relationships. Journal of Personality and Social Psychology, 78(4), 791-808. http://dx.doi.org/10.1037//00223514.78.4.791

Cross, S., Erin, H., \& Berna, G. (2009). Independent, relational, and collective-interdependent selfconstruals. In Mark R. Leary \& Rick H. Hoyle (Eds), Handbook of individual differences in social behavior, (pp. 512-526). New York: Guilford.

Cross, S., Gore, J., \& Morris, M. (2003). The relational-interdependent self-construal, self-concept consistency, and well-being. Journal of Personality and Social Psychology, 85(5), 933-944. http://dx.doi.org/10.1037/0022-3514.85.5.933

Cross, S., Hardin, E., \& Gercek-Swing, B. (2009). Independent, relational and collective-interdependent self-construals. In M. R. Leary \& R. H. Hoyle (Eds.), Handbook of individual differences in social behavior (pp. 512-526). New York: Guilford Press.

Cross, S., Morris, M., \& Gore, J. (2002). Thinking about oneself and others: The relational-interdependent self-construal and social cognition. Journal of Personality and Social Psychology, 82, 399-418. http://dx.doi.org/10.1037//0022-3514.82.3.399

Curran, P., West, S., \& Finch, J. (1996). The robustness of test statistics to nonnormality and specification error in confirmatory factor analysis. Psychological Methods, 1, 16-29. http://dx.doi.org/10.1037//1082-989X.1.1.16

Davis, M. (1980). A multidimensional approach to individual differences in empathy. JSAS Catalog of $\begin{array}{lllll}\text { Selected Documents in } 10 . & \text { Retrieved from: }\end{array}$ http://www.uv.es/ friasnav/Davis_1980.pdf

Deci, E., \& Ryan, R. (2000). Self-determination theory and the facilitation of intrinsic motivation, social development, and well-being. American Psychologist, 55(1), 68-78. http://dx.doi.org/10.1037110003-066X.55.1.68

Deci, E., \& Ryan, R. (2002). Handbook of self-determination research. New York, USA: University Rochester Press.

Fifita, I., Smith, S., \& Fernandez, K. (2015). The role of self-construal in resisting tobacco smoking. Australasian Marketing Journal, 23(4), 294-302. https://doi.org/10.1016/j.ausmj.2015.10.004

Finney, S., \& DiStefano, C. (2006). Non-normal and categorical data in structural equation modeling. In G. Hancock \& R. Mueller (eds.), Structural Equation Modeling: A Second Course (pp. 269-314). Greenwich, CT: Information Age.

Gabriel, S., \& Gardner, W. (1999). Are there "his" and "hers" types of interdependence? The implications of gender differences in collective versus relational interdependence for affect, behavior, and 
cognition. Journal of Personality and Social Psychology, 77, 642-655. http://dx.doi.org/10.1037//0022-3514.77.3.642

Gardner, W., Gabriel, S., \& Lee, A. (1999). "I" value freedom, but "we" value relationships: Self-construal priming mirrors cultural differences in judgment. Psychological Science, 10, 321-326. https://doi.org/10.1111/1467-9280.00162

Gelfand, M., Major, V., Raver, J., Nishii, L., \& O'Brien, K. (2006). Negotiating relationally: The dynamics of the relational self in negotiations. Academy of Management Review, 31, 427-451. http://dx.doi.org/10.5465/AMR.2006.20208689

Gibas, D., Giraud, T., Conte, J. Martin, J., \& Isableu, M. (2016). Attempt to validate the self-construal scale in French: systematic approach and model limitation. Revue Européenne de Psychologie Appliquée/European Review of Applied Psychology, 66(2), 85-93. https://doi.org/10.1016/j.erap.2016.02.001

Glick, P., Fiske, A., Saiz, J., Abrams, D., Masser, B., ...López, W. (2000). Beyond prejudice as simple antipathy: hostile and benevolent sexism across cultures. Journal of Personality and Social Psychology, 79(5), 763-77. http://dx.doi.org/10.1037//0022-3514.79.5.76

Gore, J., Cross, S., \& Morris, M. (2006). Let's be friends: relational self-construal and the development of intimacy. Personal Relationships, 13(1), 83-102. http://dx.doi.org/10.1111/j.14756811.2006.00106.x

Gouveia, V., Singelis, T., Guerra, V., Rivera, G., \& Vasconcelos, T. (2006). O sentimento de constrangimento: evidências acerca do contágio emocional e do género. Estudos de Psicologia - Campinas, 23(4), 329337. http://dx.doi.org/10.1590/S0103-166X2006000400002

Gudykunst, W., Matsumoto, Y., Ting-Toomey, S., Nishida, T., Kim, K., \& Heyman, S. (1996). The influence of cultural individualism-collectivism, self-construals, and individual values on communication styles across cultures. Human Communication Research, 22, 510-543. http://dx.doi.org/10.1111/j.14682958.1996.tb00377.x

Hambleton, R., Merenda, P., \& Spielberger, C. (2005). Adapting educational and psychological tests for cross-cultural assessment. Mahwah, NJ: Lawrence Erlbaum.

Hardin, E., Leong, F., \& Osipow, S. (2001). Cultural relativity in the conceptualization of career maturity. Journal of Vocational Behavior, 58, 36-52. https://doi.org/10.1006/jvbe.2000.1762

Heintzelman, S., \& Bacon, P. (2015). Relational self-construal moderates the effect of social support on life satisfaction. Personality and Individual Differences, 73, https://doi.org/10.1016/j.paid.2014.09.021

Hofstede, G. (1980), Culture's Consequences: International Differences in Work-Related Values. Beverly Hills, CA: Sage Publications.

Hu, L., \& Bentler, P. (1999). Cutoff criteria for fit indexes in covariance structure analysis: Conventional criteria versus new alternatives. Structural Equation Modeling, 6(1),1-55. http://dx.doi.org/10.1080/10705519909540118

Hui, C., \& Yee, C. (1994). The shortened individualism-collectivism scale: Its relationship to demographic and work-related variables. Journal of Research in Personality, 28(4), 409- 424. https://doi.org/10.1006/jrpe.1994.1029

Jianga, T., Canevello, A., Gore, J., Hahn, J., \& Crocker, J. (2017). The association between compassionate goals and relational-interdependent self-construal. Self and Identity, 16, 143-170. http://dx.doi.org/10.1080/15298868.2016.1238406

Jin, X., Wang, L., \& Dong, H. (2016). The relationship between self-construal and creativity - Regulatory focus as moderator. Personality and Individual Differences, 97, 282-288. https://doi.org/10.1016/j.paid.2016.03.044

Kagitçibasi, Ç. (1994). A critical appraisal of individualism and collectivism: Toward a new formulation. In U. Kim, H. Triandis, Ç. Kagitçibasi, S.-C. Choi, \& G. Yoon (Eds.), Individualism and collectivism: Theory, method, and applications (pp. 52-65). Thousand Oaks, CA: Sage Publications.

Kanagawa, C., Cross, S., \& Markus, H. (2001). "Who am I?" the cultural psychology of the conceptual self. Personality and Social Psychology Bulletin, 27, 90-103. http://dx.doi.org/10.1177/0146167201271008

Kashima, E., \& Hardie, E. (2000). The development and validation of the relational, individual, and collective self-aspects (RIC) scale. Asian Journal of Social Psychology, 3, 19-48. http://dx.doi.org/10.1111/1467-839X.00053

Kashima, Y., Kashima, E., Farsides, T., Kim, U., Strack, F., Werth, L., \& Yuki, M. (2004). Culture and contextsensitive self: The amount and meaning of context-sensitivity of phenomenal self differ across cultures. Self and Identity, 3, 125-141. http://dx.doi.org/10.1080/13576500342000095 
Kashima, Y., Yamaguchi, S., Kim, U., Choi, S.-C., Gelfand, M. J., \& Yuki, M. (1995). Culture, gender, and self: A perspective from individualism-collectivism research. Journal of Personality and Social Psychology, 69, 925-937. http://dx.doi.org/10.1037/0022-3514.69.5.925

Kenny, D., Kaniskan, B., \& McCoach, D. (2015). The performance of RMSEA in models with small degrees of freedom. Sociological Methods Research, 44(3), https://doi.org/10.1177/0049124114543236

Kim, J., Kim, M.-S., Kam, K., \& Shin, H.-C. (2003). Influence of self-construals on the perception of different self-presentation styles in Korea. Asian Journal of Social Psychology, 6, 89-101. http://dx.doi.org/10.1111/1467-839X.t01-1-00013

Kitayama, S. (2002). Culture and basic psychological processes-Toward a system view of culture: Comment on Oyserman et al. (2002). Psychological Bulletin, 128, 89-96. http://dx.doi.org/10.1037/0033-2909.128.1.89

Kitayama, S., Duffy, S., \& Uchida, U. (2007). Self as cultural mode of being. In S. Kitayama \& D. Cohen (Eds.), Handbook of cultural psychology (pp. 136-174). New York: Guilford Press.

Kuhn, M., \& McPartland, T. (1954). An empirical investigation of self-attitudes. American Sociological Review, 19(1), 68-76. http://dx.doi.org/10.2307/2088175

Leung, T., \& Kim, M. (1997). A revised self-construal scale. Department of Speech: University of Hawaii at Manoa, Honolulu, Hawaii.

Levine, T., Bresnahan, M., Park, H., Lapinski, M., Lee, T., \& Lee, D. (2003). The (In)validity of self-construal scales revisited. Human Communication Research, 29(2), 291-308. http://dx.doi.org/10.1111/j.1468-2958.2003.tb00840.x

Lu, M., Fung, H., \& Doosje, B. (2017). Intergroup conflicts: When interdependent individuals feel less dialectical than independent individuals. Personality and Individual Differences, 105, 150-157. https://doi.org/10.1016/j.paid.2016.09.027

Maddux, W., \& Brewer, M. (2005). Gender differences in the relational and collective bases for trust. $\begin{array}{llll}\text { Group Processes } \quad \text { Intergroup } & \text { 159-171. }\end{array}$ http://dx.doi.org/10.1177/1368430205051065

Mandel, N. (2003). Shifting selves and decision making: The effects of self-construal priming on consumer risk-taking. Journal of Consumer, 30(1), 30-40. http://dx.doi.org/10.1086/374700

Markus, H. (1977). Self-schemata and processing information about the self. Journal of Personality and Social Psychology, 35(2), 63-78. http://dx.doi.org/10.1037/0022-3514.35.2.63

Markus, H., \& Hamedani, M. (2007). Sociocultural psychology: The dynamic interdependence among self systems and social systems. In S. Kitayama \& D. Cohen (Eds.), Handbook of cultural psychology (pp. 3-39). New York: Guilford Press.

Markus, H., \& Kitayama, S. (1991). Culture and the self: Implications for cognition, emotion and motivation. Psychological Review, 98, 224-253. http://dx.doi.org/10.1037/0033-295X.98.2.224

Markus, H., \& Kitayama, S. (2003). Models of agency: Sociocultural diversity in the construction of action. In V.M. Berman \& J.J. Berman (Eds.), Nebraska symposium on motivation: Cross- cultural differences in perspectives on the self (Vol. 49, pp. 1-58). Lincoln: University of Nebraska Press.

Markus, H., Mullally, P., \& Kitayama, S. (1997). Selfways: Diversity in modes of cultural participation. In U. Neisser \& D. Jopling (Eds.), The conceptual self in context (pp.13-61). New York: Cambridge University Press.

Marôco, J. (2011). Análise Estatística com o SPSS Statistics (5 $5^{\text {th }}$ ed.) [Statistic Analysis with SPSS Statistics]. Pero Pinheiro: Report Number.

Marôco, J. (2014). Análise de equações estruturais: Fundamentos teóricos, software e aplicações [Structural equations analysis: Theoretical fundamentals, software and applications]. Pero Pinheiro: Report Number.

Neto, F. (1995). Alocentrismo nos estudantes universitários [Alocentrism in university students]. Revista Portuguesa de Pedagogia, 29(1), 21-36.

Nisbett, R. (2003). The geography of thought: How Asians and Westerners think differently...and why. New York: Free Press.

Nunnally, J. (1978). Psychometric theory (2 ${ }^{\text {nd }}$ ed.). New York: McGraw-Hill.

Nunnally, J., \& Bernstein, I. (1994). Psychometric theory. New York: McGraw-Hill.

Oetzel, J., \& Bolton-Oetzel, K. (1997). Exploring the relationship between self-construal and dimensions of group effectiveness. Management Communication Quarterly, 10(3), 289-315. https://doi.org/10.1177/0893318997010003002

Oguri, M., \& Gudykunst, W. (2002). The influence of self-construal and communication styles on sojourners' psychological and sociocultural adjustment. International Journal of Intercultural Relations, 26, 577-593. https://doi.org/10.1016/S0147-1767(02)00034-2 
Oyserman, D., Coon, H., \& Kemmelmeier, M. (2002). Rethinking individualism and collectivism: Evaluation of theoretical assumptions and meta-analyses. Psychological Bulletin, 128(1), 3-72. http://dx.doi.org/10.1037//0033-2909.128.1.3

Ozawa, K., Crosby, M., \& Crosby, F. (1996). Individualism and resistance to affirmative action: A comparison of Japanese and American samples. Journal of Applied Social Psychology, 26, 11381152. http://dx.doi.org/10.1111/j.1559-1816.1996.tb02289.x

Petrella, M., \& Gore, J. (2013). Relational Self-Construal and its relationship to academic citizenship behavior. Psychol. Stud., 58(2), 115-121. https://doi.org/10.1007/s12646-013-0182-1

Pratt, M., Prancer, M., Hunsberger, B., \& Manchester, J. (1990). Reasoning about the self and relationships in maturity: An integrative complexity analysis of individual differences. Journal of Personality and Social Psychology, 59, 575-581. http://dx.doi.org/10.1037/0022-3514.59.3.575

Rahat, E., \& Ílhan, T. (2016). Coping styles, social support, relational self-construal, and resilience in predicting students' adjustment to University life. Educational Sciences: Theory \& Practice, 16(1), 187-208. http://dx.doi.org/10.12738/estp.2016.1.0058

Russel, L., Gould, K., \& Fergus, T. (2007). Self-construal and gender interact to cause social evaluative concerns. Personality and Individual Differences, 109, 51-55. https://doi.org/10.1016/j.paid.2016.12.041

Sato, T., \& Cameron, J. (1999). The relationship between collective self-esteem and self-construal in Japan and Canada. The Journal of Social Psychology, 139, 426-435. http://dx.doi.org/10.1080/00224549909598402

Sedikides, C., \& Brewer, M. (2001). Individual self, relational self, and collective self: Partners, opponents, or strangers? In C. Sedikides, \& M. B. Brewer (Eds.), Individual self, relational self, collective self (pp. 1-4). Philadelphia: Taylor \& Francis.

Singelis, T. (1994). The measurement of independent and interdependent self-construals. Personality and Social Psychology Bulletin, 20, 580-591. https://doi.org/10.1177/0146167294205014

Singelis, T., \& Brown, W. (1995). Culture, self, and collectivist communication: Linking culture to individual behavior. Human Communication Research, 21(3), 354-389. http://dx.doi.org/10.1111/j.1468-2958.1995.tb00351.x

Singelis, T., \& Sharkey, W. (1995). Culture, self-construal, and embarrassability. Journal of Cross-Cultural Psychology, 26, 622-644. https://doi.org/10.1177/002202219502600607

Singelis, T., Bond, M., Sharkey, W., \& Lai, K. (1999). Unpackaging culture's influence on self-esteem and embarrassability: The role of self-construals. Journal of Cross-Cultural Psychology, 30, 315-341. https://doi.org/10.1177/0022022199030003003

Sousa, C., Gonçalves, G., \& Cunha, M. (2015). Cultural values as a support to the development of intercultural competences. Spatial and Organizational Dynamics - Discussion Papers, 14, 7-22.

Suh, E. (2002). Culture, identity consistency, and subjective well-being. Journal of Personality and Social Psychology, 83, 1378 - 1391. http://dx.doi.org/10.1037/0022-3514.83.6.1378

Triandis, H. (1989). The self and social behavior in different cultural contexts. Psychological Review, 96, 269-289. http://dx.doi.org/10.1037/0033-295X.96.3.506

Triandis, H. (1994). Culture and social behavior. New York: MacGraw-Hill.

Triandis, H., McCusker, C., \& Hui, C. (1990). Multimethod probes of individualism and collectivism. Journal of Personality and Social Psychology, 59, 1006-1020. http://dx.doi.org/10.1037/00223514.59.5.1006

Ullman, J. (2006). Structural equation modeling: Reviewing the basics and moving forward. Journal of Personality Assessment, 87(1), 35-50. http://dx.doi.org/10.1207/s15327752jpa8701_03

Vandello, J., \& Cohen, D. (1999). Patterns of individualism and collectivism across the United States. Journal of Personality and Social Psychology, 77(2), 279-292. http://dx.doi.org/10.1037/00223514.77.2.279

Watkins, C. (1989). Learning from delayed rewards. [PhD Thesis], University of Cambridge, England.

West, S., Finch, J., \& Curran, P. (1995). Structural equation models with non-normal variables: Problems and remedies. In R. Hoyle (Ed.), Structural equation modeling: Concepts, issues, and applications (pp. 56-75). Thousand Oaks, CA: Sage.

Worthington, R., \& Whittaker, T. (2006). Scale development research: A content analysis and recommendations for best practices. The Counseling Psychologist, 34(6), 806-838. http://dx.doi.org/10.1177/0011000006288127

Yamada, A., \& Singelis, T. (1999). Biculturalism and self-construal. International Journal of Intercultural Relations, 23, 697-709. https://doi.org/10.1016/S0147-1767(99)00016-4 
Zuckerman, D. (1985). Confidence and aspirations: Self-esteem and self-concepts as predictors of students' life goals. Journal of Personality, 53, 543-560. http://dx.doi.org/10.1111/j.14676494.1985.tb00382.x

\section{Historial do artigo}

Recebido $\quad 10 / 01 / 2017$

Aceite $\quad 27 / 07 / 2017$

Publicado $11 / 2017$

0 processo de revisão deste artigo foi responsabilidade da anterior direção da revista Psicologia 


\section{APPENDIX \\ RISC scale - Portuguese Version (RISC-P)}

Leia cada afirmação e selecione a resposta que MELHOR o descreve numa escala crescente de 1 (discordo totalmente) a 7 (concordo totalmente):

1. Os meus relacionamentos íntimos são um importante reflexo de quem sou. [My close relationships are an important reflection of who I am]

2. Quando me sinto muito íntimo de alguém, fico frequentemente com a impressão que essa pessoa é uma parte importante de quem eu sou. [When I feel very close to someone, it often feels to me like that person is an important part of who I am

3. Normalmente, sinto muito orgulho quando alguém que me é próximo consegue uma realização importante. [I usually feel a strong sense of pride when someone close to me has an important accomplishment]

4. Vendo e percebendo os meus relacionamentos íntimos consegue-se compreender uma parte importante de quem sou eu. [I think one of the most important parts of who I am can be captured by looking at my close friends and understanding who they are]

5. Quando penso em mim, penso frequentemente nas pessoas íntimas. [When I think of myself, I often think of my close friends or family also]

6. Se magoarem alguém íntimo, sinto-me igualmente magoado. [If a person hurts someone close to me, I feel hurt as well]

7. Geralmente, as minhas relações íntimas são uma parte importante da minha autoimagem. [In general, my close relationships are an important part of my self-image]

8. Os meus relacionamentos íntimos são importantes para a perceção que faço de mim próprio. [My close relationships are unimportant to my sense of what kind of person I am]

9. Eu tenho orgulho por saber quem são os meus relacionamentos íntimos. [My sense of pride comes from knowing who I have as close friends]

10. Quando estabeleço uma relação íntima com alguém, geralmente desenvolvo um forte sentimento de identificação com essa pessoa. [When I establish a close friendship with someone, I usually develop a strong sense of identification with that person]

.

Note: As a translation of the concept of Relational Interdependent Self-Construal we propose: Relational Interdependent SelfInterpretation (RISI) or in the short form: Relational Self-Interpretation (In Portuguese: Auto-Interpretação Relacional Interdependente (AIRI) ou Auto-Interpretação Relacional). 